International Journal of Instruction e-ISSN: 1308-1470 • www.e-iji.net

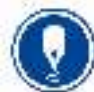

January $2021 \bullet$ Vol.14, No.1

p-ISSN: 1694-609X

pp. $999-1018$

Article submission code:

20200322134216
Received: 22/03/2020

Revision: 15/08/2020
Accepted: 07/09/2020

OnlineFirst: 16/12/2020

\title{
An Analysis of the Causal Relationships in Sustainable Consumption Behaviour (SCB) of Thai Student Science Teachers
}

\section{Paitoon Pimdee}

Assoc. Prof. Dr., Faculty of Industrial Education and Technology, King Mongkut's Institute of Technology Ladkrabang (KMITL), Thailand, paitoon.pi@kmitl.ac.th

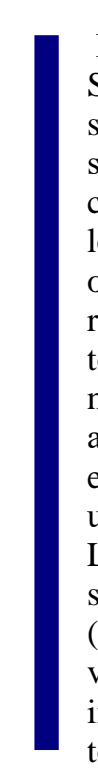

Having its originations in the 1987 UN Brundtland Report and the 1994 Oslo Symposium for sustainable consumption and production (SCP), education for sustainable development (ESD) has taken on global importance. As such, the study's author sought to examine the causal relationships on sustainable consumption behaviour (SCB) of Thai student science teachers, as these are the leaders of tomorrow. The sample of 200 men and 200 women was obtained by use of multistage random sampling from ten state universities located across 5 Thai regions. The research tool was a 5-level response questionnaire consisting of 130 total items examining 18 observed variables, of which 97 items were positive in nature, while the remaining 33 items were negative in nature. The IOC was used to assess the questionnaire's development process by the three teacher training experts. Subsequent item reliability testing of the pilot test group of 62 individuals used Cronbach's Alpha $(\alpha)$ to judge reliability. Further data analysis made use of LISREL 9.1 software on the interrelationships of the latent variables psychological state (PS), environmental education (EE), psychological traits (PT), situation (SIT), as well as their effect on SCB. Results revealed that all the model's causal variables had a positive effect on SCB, which can be explained by the combined influence of the factors $\left(\mathrm{R}^{2}\right)$ being $92 \%$. Furthermore, four factors were determined to influence SCB. Ranked in importance, these included SIT, EE, PS, and PT.

Keywords: education for sustainable development, ESD, SDGs, student situation, sustainable development goals, Thailand

\section{INTRODUCTION}

In 1987, the United Nations (UN) issued the Brundtland Report (WCED, 1987) to introduce a global concept of sustainable development (SD), with the aim being to identify and find sustainable solutions for the world's next generations on a planet with limited resources. Subsequently, in the Oslo Symposium in 1994, sustainable consumption and production (SCP) was combined, and further defined as the manner in which services and related products are used (Leicht et al., 2018). Furthermore, SCP is about how basic needs and a better quality of life is achieved while minimizing the use

Citation: Pimdee, P. (2021). An Analysis of the Causal Relationships in Sustainable Consumption Behaviour (SCB) of Thai Student Science Teachers. International Journal of Instruction, 14(1), 9991018. https://doi.org/10.29333/iji.2021.14159a 
of natural resources and toxic materials as well as the emissions of waste and pollutants. To achieve these high goals, the concept of Education for Sustainable Development (ESD) is commonly stated as the encouragement of changes in knowledge, skills, values, and attitudes to enable a more sustainable and just society for all (Leicht et al., 2018). ESD is also about the empowerment of learners by educators who can provide the knowledge, skills, values, and attitudes that contribute to SD. At the same time, it is imperative that institutions must strengthen their agendas, programs, and activities which promote SD (United Nations, 2015).

In 2017, Thailand presented its Voluntary National Review (VNR) at the High-level Political Forum on Sustainable Development (HLPF) in New York at the United Nations Headquarters (Minister of Foreign Affairs, 2018). Thai government agencies under the National Committee for Sustainable Development (CSD) subsequently agreed that the VNR process had helped create a sense of ownership from stakeholders over the country's development efforts, kept all parties updated on the implementation status of each of the SDGs and built bridges of partnership between all sectors of society, be it government, the private sector, academia or civil society, in jointly advancing the SDGs in Thailand.

Subsequently, in a 2018 UNESCO sponsored workshop in Bangkok, Thailand, the title of the meeting was entitled 'Sustainability Begins with Teachers' (UNESCO, 2018) which was further focused on teacher education in Southeast Asia. Educators were further exposed to the United Nation's Sustainable Development Goals (SDGs) for implementation and achievement by all the countries by 2030. To facilitate the transition of the planet and the global society to a sustainable world, the UN SDGs demand that by 2030, "all learners acquire knowledge and skills needed to promote sustainable development..." (SDG 4 Target 7) and that "people everywhere have the relevant information and awareness for sustainable development" (SDG 12 Target 8) (United Nations, 2020a, 2020b).

Simultaneously, in 2018, Thailand formally launched the 20-Year National Strategy Framework (2017 - 2036) as a development framework for the whole of government to realize the vision of 'Thailand as a developed country with security, prosperity and sustainability in accordance with the principle of 'Sufficiency Economy Philosophy' (Minister of Foreign Affairs, 2018). Thailand has also continued to implement the National Education Plan 2017 - 2036 which is in line with SDG 4. Moreover, Science, Technology, Engineering and Mathematics (STEM) education has been integrated into basic education and a Vocational Boot Camp for E to E (Education to Employment) has been established.

Along with educational initiatives, resource use and environmental degradation should be reduced, or 'doing more and better with less.' SDG 12 specifically discusses SCP in a context of promoting resource and energy efficiency, sustainable infrastructure, and providing access to basic services, green and decent jobs and a better quality of life for all (United Nations, 2020b). This includes educating consumers on sustainable consumption and lifestyles, providing them with adequate information through standards and labels and engaging in sustainable public procurement, among others (Sethna \& 
Blythe, 2019). However, 'behavioural change' initiatives which encourage citizens to assume greater 'personal responsibility' for their lifestyles and their 'choices' in the market-place is difficult at best (McMeekin \& Southerton, 2012). Therefore, SCB must be addressed at an early stage of an individual's citizen development. Educators are, therefore, crucial in the ESD process with Narathakoon et al. (2020) stating that in recent times there has been an ever increasing interest in teachers' beliefs, as beliefs can predict teaching behaviour (Muijs et al., 2014).

\section{Literature Review}

Research from Inayatullah (2009) has provided scholars with insight into how the European Union (EU) views the world's economy and its environmental problems. In addition, both the social and physical environmental and the 'interaction' of these 'two worlds' are discussed. The EU's concepts, however, found their foundation in previous research from Endler and Magnusson (1976) and Endler (1983) in which an individual's 'interaction' is discussed as four personality models. These include trait psychology, psychodynamics, situationism, and interactionism. Therefore, the author chose these concepts in conjunction with EE to investigate the interrelationships of SCB on Thai student science teachers for this study (Tett \& Burnett, 2003; Walsh et al., 2012).

\section{Psychological Traits (PTs)}

According to Engel and Weber (2007), PTs are how institutions shape childhood and adolescence experiences and their behaviour. In the Theory of Planned Behavior (an extension of the Theory of Reasoned Action) (Fishbein \& Ajzen 1975, Ajzen \& Fishbein 1980), both models are based on the premise that individuals make logical, reasoned decisions to engage in specific behaviour by evaluating the information available to them (Ryan \& Carr, 2010). In other words, the Theory of Reasoned Action suhhests that behaviour results from our behavioral intentions, which themselves depend on attitudes towards these behaviours (Luchs et al., 2015). In Thailand, the scholar Bhanthumnavin $(1995,2000,2017)$ places these ideas in an Asian context in what translates as the Ethical Tree Theory (ETT). The ETT proposes that psychological causes are divided into two parts, one being the roots, and one being the trunk (Pimdee, 2017), with the trunk consisting of five PT aspects. These PT aspects are the motive for achievement, future orientation and self-control, internal locus of control, moral reasoning and attitude values and morals. Thus, the observed variables selected for PTs' investigation include the internal locus of control (x1), future orientation with selfcontrol (x2), and good mental health (x3). Finally, from the above, other theory, and related literature, the author proposes the following two hypotheses:

\section{H1: PTs influences EE. \\ H2: PTs influences PS.}

\section{Situation (SIT)}

In Bhanthumnavin's $(1995,2000)$ ETT, unlike the trunk, the roots contain four elements including mental faculties, intelligence, social skills, and experience. Bowers (1973) earlier stated that behaviour is more situation-specific and that situations are more 
person-specific than is commonly recognized. Thus, the observed variables selected for SIT's investigation include the social norm awareness $(\mathrm{x} 4)$, family parenting $(\mathrm{x} 5)$, and example from friends (x6). Finally, from the above, other theory, and related literature, the author proposes the following three hypotheses:

\section{H3: SIT influences EE. \\ H4: SIT influences SCB.}

\section{H5: SIT influences PS.}

\section{Psychological State (PS)}

In research conducted by Luchs et al. (2015), consumer responsibility was investigated, specifically as it relates sustainable consumption. The results suggested that consumer responsibility may be a better predictor of sustainable consumption behaviour than attitudes towards sustainability. Furthermore, responsibility was defined in terms of cognition, emotion, as a moral imperative, and finally, as socioculturally shaped. Gotyal et al. (2010) has also stated that PS is a mental process, which is dynamic style resulting from the present situation combined with the nature of the individual's spirituality (Bajpai \& Saha, 2020). This is therefore closely related to behavior. Bhanthumnavin (2000) also added that the PS consists of attitude, stress, and knowledge. This is supported by research from Sharma and Rani (2014) who stated that there is a gap between positive attitudes toward sustainability and people's unsustainable consumption behavior, with numerous studies finding that attitude is an influencing factor for such behavior. Thus, the observed variables selected for PS's investigation include the student teacher's GPA (y6), their sustainable consumption attitude (y7), and social responsibility inspiration (y8). Finally, from the above, other theory, and related literature, the author proposes the following hypothesis:

\section{H6: PS influences SCB.}

\section{Environmental Education (EE)}

Furthermore, according to Trudel (2018), understanding SCB is central to any paradigm shifts in how society approaches environmental problems. In research from Steg et al. (2016) concerning how behaviour affects pro-environmental behaviour, it was stated that there are three types of goals underlying behaviour. These include the hedonic goal to feel good, the gain goal to enhance one's resources, and the normative goal to act appropriately.Hungerford and Volk (1990) further stated that EE should develop an individual's personal and social potential, while creating an awareness of environmental issues, as the ultimate aim of education is shaping human behaviour. Specifically, in the world's first intergovernmental conference on environmental education in Tbilisi, Georgia in 1977, five aspects were detailed. These included awareness, knowledge, attitudes, skills, and participation (Tbilisi Declaration, 1977). However, even before the Tbilisi Declaration, Stapp (1969) had written that EE should be involved with producing a citizenry that is aware of their biophysical environment, its problems, its solutions, with motivation to work towards a common solution. Thus, the observed variables selected for EE's investigation include the student teacher's attitude toward the 
environment (y9), value to the environment (y10), conservation evaluation (y11), and conservation participation (y13). Finally, from the above, other theory, and related literature, the author proposes the following two hypotheses:

H7: EE influences PS.

H8: EE influences SCB.

\section{METHOD}

\section{Population and Sample}

The study's population were undergraduate student teachers in science related fields, such as chemistry, biology, physics, mathematics, and environmental studies. The population size at the time of the study was estimated to be around 94,600 student teachers who were enrolled in teacher training programs in ten Thai Universities (Table 1). Moreover, according to Brown (2015), the statistical power and precision of a CFA and SEM parameter estimates are influenced by the sample size. Additionally, according to Loehlin (1992), results from Monte Carlo simulation studies using confirmatory factor analysis (CFA) models suggests that an investigator's sample is $\geq 200$ individuals. In this study, the author defined the size of the sample as being equal to 400 . The sampling was then undertaken using multistage random sampling. This process consisted of simple random sampling using the lottery method for each of the 10 Rajabhat universities in five Thai regions. From each institution's Faculty of Education, 20 women and 20 men were selected. Stratified random sampling was subsequently conducted according to gender, when the sample size of each gender from each region was the same.

Table 1

Number of students selected according to region, university, and gender

\begin{tabular}{lllll}
\hline \multirow{2}{*}{ Region } & \multicolumn{1}{c}{ University } & \multicolumn{2}{l}{ Gender } & \multirow{2}{*}{ Total } \\
\cline { 3 - 5 } North & 1.Chiang Rai Rajabhat University & 20 & 20 & 40 \\
& 2. Chiang Mai University & 20 & 20 & 40 \\
\hline \multirow{2}{*}{ Northeast } & 3. Sisaket Rajabhat University & 20 & 20 & 40 \\
& 4. Khon Kaen University & 20 & 20 & 40 \\
\hline \multirow{2}{*}{ Central } & 5. Phetchaburi Rajabhat University & 20 & 20 & 40 \\
& 6. Burapha University & 20 & 20 & 40 \\
\hline \multirow{2}{*}{ Bangkok } & 7. Bansomdejchaopraya Rajabhat University & 20 & 20 & 40 \\
& 8. Srinakharinwirot University & 20 & 20 & 40 \\
\hline \multirow{2}{*}{ Southern } & 9. Nakhon Si Thammarat Rajabhat University & 20 & 20 & 40 \\
& 10. Prince of Songkla University & 20 & 20 & 40 \\
\hline \multirow{2}{*}{ Total } & & 200 & 200 & 400 \\
\hline
\end{tabular}

\section{Research Tool}

The research tool was a questionnaire related to SCB and each student teacher's personal characteristics. The questionnaire was developed by the author and evaluated 
and improved by other academics and researchers. The questionnaire contained a 5-level response scale (except for GPA scores) consisting of 130 total items examining 18 observed variables, of which 97 items were positive in nature, while the remaining 33 items were negative in nature. The questionnaire used a summated rating scale with 5 levels which is presented in Table 2.

Table 2

Criteria for student teacher opinion ranking

\begin{tabular}{lll}
\hline \multirow{2}{*}{ Opinion level } & \multicolumn{2}{l}{ Criteria for score rating } \\
\cline { 2 - 3 } & Positive & Negative \\
\hline Most / Strongly agree & 5 & 1 \\
More / Agree & 4 & 2 \\
Moderate / Neutral & 3 & 3 \\
Less / Disagree & 2 & 4 \\
Least / Strongly disagree & 1 & 5 \\
\hline
\end{tabular}

\section{Questionnaire Development and Testing}

The questionnaire's content validity was evaluated by three education experts who were university lecturers, after which, content validity verification was measured using the suggested criteria of an indexes of item-objective congruence (IOC) $\geq 0.50$ (Turner \& Carson, 2003). However, a higher standard was suggested. Therefore, any items which received an IOC of less than 0.67 were removed or re-written according to the experts' suggestions. The reliability of the questionnaire was then evaluated using 62 undergraduate students from a Faculty of Education from state universities in Thailand (not used in the final sample). Assessment of the pilot-test reliability was done from use of Cronbach's $\alpha$.

\section{Data Collection}

A questionnaire was used to collect data from the undergraduate students through the research team coordinating via networks at each sampled university. The team collected data from ten Thai Universities across five regions starting in May 2014 (Table 1). From each university's Faculty of Education, 40 students were randomly selected. In the beginning, only 328 questionnaires were returned with an $82 \%$ completion rate. Therefore, the author and research team again performed additional sampling, and collected additional questionnaires from the same ten universities again in August 2014. This resulted in a total of 400 completed questionnaires. The questionnaires were classified according to gender, with each group equal at 200 student teachers each

\section{Data Analysis}

To determine the importance and a summary of each variable, descriptive statistics were used. Standard testing includes analysis for the mean and the standard deviation (S.D.) (Boonkua et al., 2020). LISREL 9.10 software program was used to conduct the Confirmatory Factor Analysis (CFA) and the follow-on structural equation modelling (SEM) between variables influencing Thai student teacher SCB. Interpretation of the accuracy of the SEM on SCB made use of goodness-of-fit (GOF) criteria. If the 
calculated statistic passed the established GOF criteria, it supported the model's accuracy being consistent with the empirical data.

\section{FINDINGS}

\section{Student Teacher Characteristics}

Table 3 shows three items from the survey concerning each student's type of current residence, their family's income per month in Thai baht, and finally, the highest level of education obtained by a parent. Results show that $77.25 \%$ of the student teachers reside in some form of dormitory, either on or off campus, while another $15.75 \%$ said they live with their parents at home. Concerning each student teacher's family income, it seems student teachers come from poor to middle class families. The reported data indicates that a slight majority $(30.5 \%)$ came from families who reported family income between $\$ 311$ and $\$ 622$ per month, while other students reported their family income between $\$ 934$ and $\$ 1,245(29.5 \%)$. Rather surprisingly, another $20.75 \%$ reported their family unit earned less than $\$ 311$ per month. Finally, parental education was also very diverse, with the largest majority having a bachelor's degree or higher $(28.25 \%)$. Rather surprising again was the reported $26.25 \%$ who reported that both parents had not only a primary school education or lower. Another 20.25\% reported that one of their parents had made it to high school graduation or obtained a vocational certificate.

Table 3

Student teacher characteristics

\begin{tabular}{lll}
\hline List & Number & $\%$ \\
\hline Resident type & 63 & 15.75 \\
$\quad$ - Own house & 309 & 77.25 \\
- Dormitory (Internal/external) & 27 & 6.75 \\
- Relatives/acquaintances house & 1 & 0.25 \\
$\quad$ - Others such as temple & 400 & 100.00 \\
\hline Total & & \\
\hline Family income (per month) & 83 & 20.75 \\
$\quad$ - Less than 10,000 THB (USD\$311) & 122 & 30.50 \\
- 10,001 - 20,000 THB & 77 & 19.25 \\
- 20,001 - 30,000 THB & 118 & 29.50 \\
$\quad$ - 30,001 - 40,000 THB & 400 & 100.00 \\
\hline Total & & \\
\hline Parents' highest education degree & 105 & 26.25 \\
- Primary school or lower & 41 & 10.25 \\
- Junior High School & 81 & 20.25 \\
- Senior High School or vocational certificate & 60 & 15.00 \\
- Diploma/ high vocational certificate & 113 & 28.25 \\
- Bachelor's Degree or higher & 400 & 100.00 \\
\hline Total
\end{tabular}




\section{The Goodness-of-Fit (GOF) Analysis}

The study's LISREL 9.1 CFA included a GOF analysis to determine how well the model fit with the data, with validity being measured by use of convergent validity $(\mathrm{CV})$ to assure that the expected relationships between the constructs do exist. Hooper et al. (2005) has stated that CV includes GFI, CFI, RMSEA, and the chi-square/df statistic, with discriminant validity also being used in the GOF assessment (Henseler et al., 2014). From this, we note that the recommended Chi-square $(\chi 2)$ value of $p \geq 0.05$ was met (study's value $=0.70)$. The relative Chi-square $(\chi 2 / \mathrm{df})$ of $\leq 2.00$ was also met (study's value $=0.85)$ (Tabachnick \& Fidell, 2007). Other scholars have recommended that the values for RMSEA, RMR, and SRMR should be $\leq 0.05$ (Hu \& Bentler, 1999). These criteria were met as the study's values were $0.00,0.01$, and 0.01 , respectively. Moreover, the GFI, AGFI, NFI, and CFI should all be $\geq 0.90$ (Schumacker \& Lomax, 2010). The study's values for these three values were $0.99,0.95,0.99$, and 1.00 , respectively. Based on the suggested values from the literature and those provided from the analysis, the authors concluded that the data matched the model.

\section{CFA of Latent and Observed Variables}

Jöreskog et al. (2016) have suggested prior to SEM testing; a CFA should be done to assess construct validity. Also, in conducting a CFA, it is suggested that there be at least three observed variables for each latent variable. In this study, this criterion has been met. Thirdly, when considering construct validity, Campbell and Fiske (1959) suggest using discriminant validity (DV) and convergent validity (CV) as measurement tools. In addition, Hair et al. (2013) has reported that $\mathrm{CV}$ is best achieved using the average variance extracted (AVE), main loadings, and composite/construct reliability (CR). Furthermore, CR is how the surveyed individuals respond, while CV is used as the measurement means. Moreover, the AVE should $\geq 0.5$ and CR should $\geq 0.6$. The AVE estimate is the average amount of variation that a latent construct is able to explain in the observed variables to which it is theoretically related. This correlation is generally referred to as a factor loading (Farrell, 2009). However, if the AVE is $\leq 0.5$, but CR is higher than 0.6, the CV of the construct is still acceptable (Fornell et al., 1996). From the study's analysis, the AVE/CR relationship was $\mathrm{SCB}=0.41 / 077, \mathrm{PS}=0.59 / 0.80, \mathrm{EE}$ $=0.62 / 0.87, \mathrm{PT}=0.48 / 0.70$, and SIT $=0.47 / 0.72$. ). These results support testing validity (Table 4). It is also desirable that standardized loadings are statistically significant and adequately high $(\geq .50$ and, ideally, $\geq .707)$ Barclay et al. (1995), showing that more than $50 \%\left(.707^{2}\right)$ of an indicator's variance is explained by its respective construct (Carneiro et al., 2009), while the rest is (random or indicatorspecific) measurement error (Hair et al., 2009).Concerning Cronbach's $\alpha$ values, George and Mallery (2003) have suggested the following scale: $\alpha \geq .9$ is excellent, $\geq .8$ is good, $\geq .7$ is acceptable, $\geq .6$ is questionable, and $\geq .5$ is poor to unacceptable). Therefore, a Cronbach $\alpha$ value between .6 and .7 are considered adequate (Lance et al., 2006 
Table 4

CFA of latent and observed variables

\begin{tabular}{|c|c|c|c|c|c|c|c|}
\hline $\begin{array}{l}\text { Latent } \\
\text { Variables }\end{array}$ & & $\alpha$ & Observed Variables & Loading & $\mathrm{R}^{2}$ & AVE & $\mathrm{CR}$ \\
\hline \multirow[t]{5}{*}{ SCB } & y1 & 0.72 & $\begin{array}{l}\text { Environmental knowledge } \\
\text { dissemination }\end{array}$ & 0.70 & 0.49 & \multirow[t]{5}{*}{0.41} & \multirow[t]{5}{*}{0.77} \\
\hline & $\mathrm{y} 2$ & 0.61 & Product use selection & 0.67 & 0.45 & & \\
\hline & $\mathrm{y} 3$ & 0.69 & Product purchase selection & 0.66 & 0.43 & & \\
\hline & $\mathrm{y} 4$ & 0.85 & Learning and participation & 0.62 & 0.39 & & \\
\hline & y5 & 0.77 & Resource saving & 0.52 & 0.27 & & \\
\hline \multirow[t]{3}{*}{ PS } & y6 & - & GPA & 0.97 & 0.93 & \multirow[t]{3}{*}{0.59} & \multirow[t]{3}{*}{0.80} \\
\hline & y7 & 0.71 & $\begin{array}{l}\text { Good attitude toward sustainable } \\
\text { consumption }\end{array}$ & 0.40 & 0.26 & & \\
\hline & y8 & 0.85 & Sustainable consumption attitude & 0.82 & 0.68 & & \\
\hline \multirow[t]{4}{*}{$\mathrm{EE}$} & y9 & 0.81 & Attitude toward the environment & 0.64 & 0.41 & \multirow[t]{4}{*}{0.62} & \multirow[t]{4}{*}{0.87} \\
\hline & y10 & 0.62 & Value to the environment & 0.81 & 0.65 & & \\
\hline & y11 & 0.68 & Conservation evaluation & 0.81 & 0.66 & & \\
\hline & y12 & 0.73 & Conservation participation & 0.87 & 0.75 & & \\
\hline \multirow[t]{3}{*}{ PT } & $\mathrm{x} 1$ & 0.65 & Internal locus of control & 0.23 & 0.15 & \multirow[t]{3}{*}{0.48} & \multirow[t]{3}{*}{0.70} \\
\hline & $\mathrm{x} 2$ & 0.75 & $\begin{array}{l}\text { Future orientation with self- } \\
\text { control }\end{array}$ & 0.76 & 0.58 & & \\
\hline & $\mathrm{x} 3$ & 0.81 & Good mental health & 0.90 & 0.81 & & \\
\hline \multirow[t]{3}{*}{ SIT } & $\mathrm{x} 4$ & 0.77 & Social norm awareness & 0.81 & 0.65 & \multirow[t]{3}{*}{0.47} & \multirow[t]{3}{*}{0.72} \\
\hline & $x 5$ & 0.78 & Family parenting & 0.50 & 0.25 & & \\
\hline & $x 6$ & 0.82 & Example from friends & 0.72 & 0.52 & & \\
\hline
\end{tabular}


Table 5

Descriptive analysis of the latent and observed variables

\begin{tabular}{|c|c|c|c|c|c|c|}
\hline Latent and Observed Variables & Name & Items & Mean & SD. & Skew $^{1}$ & Kurt $^{2}$ \\
\hline SCB & SCB & 23 & & & & \\
\hline Environmental knowledge dissemination & y1 & 5 & 3.50 & .66 & -.25 & .06 \\
\hline Product use selection & y2 & 5 & 3.85 & .58 & -.36 & -.08 \\
\hline Product purchase selection & y3 & 5 & 3.66 & .56 & -.09 & .59 \\
\hline Learning and participation & y4 & 4 & 3.75 & .58 & -.49 & .68 \\
\hline Resource saving & y5 & 4 & 4.07 & .52 & -.19 & -.36 \\
\hline $\mathrm{PS}$ & PS & 34 & & & & \\
\hline GPA & y6 & 1 & 2.94 & .54 & .04 & -1.06 \\
\hline Sustainable consumption attitude & y7 & 12 & 3.67 & .52 & .07 & -.42 \\
\hline Social responsibility inspiration & y8 & 21 & 3.84 & .50 & -.18 & -.36 \\
\hline $\mathrm{EE}$ & EE & 16 & & & & \\
\hline Attitude toward the environment & y9 & 4 & 4.12 & .59 & -.48 & .38 \\
\hline Value to the environment & y10 & 4 & 3.86 & .59 & -.11 & -.22 \\
\hline Conservation evaluation & y11 & 4 & 3.79 & .58 & .02 & -.24 \\
\hline Conservation participation & y12 & 4 & 3.82 & .56 & .00 & -.39 \\
\hline PT & PT & 24 & & & & \\
\hline Internal locus of control & $\mathrm{x} 1$ & 9 & 4.00 & .68 & -.44 & -.85 \\
\hline Future orientation with self-control & $\mathrm{x} 2$ & 8 & 3.57 & .54 & -.02 & .37 \\
\hline Good mental health & $\mathrm{x} 3$ & 7 & 3.71 & .55 & -.14 & .08 \\
\hline SIT & SIT & 33 & & & & \\
\hline Social norm awareness & $\mathrm{x} 4$ & 13 & 14.44 & 3.97 & .29 & -.12 \\
\hline Family parenting & $\mathrm{x} 5$ & 9 & 3.25 & .63 & .27 & -.03 \\
\hline Example from friends & $\mathrm{x} 6$ & 11 & 3.76 & .54 & -.27 & .70 \\
\hline
\end{tabular}

${ }^{1}$ Skewness $\leq|1|$ (Hair et al., 2009) ${ }^{2}$ Kurtosis $\leq|7|$ (Curran et al., 1996)

It was determined that all the SEM's causal variables positively influenced a Thai student teacher's SCB , which can be combined to explain the shared variance of the factors affecting SCB $\left(\mathrm{R}^{2}\right)$ by $92 \%$ (Table 6). Additionally, Table 4 details the effect values from the Coefficient of Influence (R) testing (Ladhari, 2009), with $R$ having the potential to have a value from -1 to +1 (Ratner, 2009) whose variable relationship increases as the value of the coefficient increases. Furthermore, four factors were determined to be influencing SCB. Ranked in importance, these included SIT, EE, PS, and PT. Their total effect (TE) value strengths were $0.87,0.34,0.22$, and 0.08 , respectively. 
Table 6

Standard coefficient of influence in the causal relationships of student teacher SCB

\begin{tabular}{lllll}
\hline \multirow{2}{*}{ Causal factors } & \multirow{2}{*}{ Effect } & \multicolumn{4}{l}{ Dependent Variables } \\
\cline { 3 - 5 } & & SCB & PS & EE \\
\hline \multirow{2}{*}{ PT } & Direct & - & 0.21 & 0.11 \\
& Indirect & 0.08 & 0.01 & - \\
& Total & 0.08 & 0.22 & 0.11 \\
\hline \multirow{2}{*}{ SIT } & Direct & $0.52^{* *}$ & $0.46^{*}$ & $0.75^{* *}$ \\
& Indirect & $0.35^{* *}$ & 0.09 & - \\
& Total & $0.87^{* *}$ & $0.55^{*}$ & $0.75^{* *}$ \\
\hline \multirow{2}{*}{ PS } & Direct & $0.22^{*}$ & - & - \\
& Indirect & - & - & - \\
\hline \multirow{2}{*}{$\mathrm{EE}$} & Total & $0.22^{*}$ & - & - \\
& Direct & $0.31^{*}$ & 0.13 & - \\
\hline $\mathrm{R}^{2}$ & Indirect & 0.03 & - & - \\
\hline
\end{tabular}

$* p \leq .05, * * p \leq .01$

Table 7 and Figure 1 detail the results of the final hypotheses testing.

Table 7

Hypothesis testing summary

\begin{tabular}{llll}
\hline Hypotheses & Coef. & t-test & Findings \\
\hline H1: PTs influences EE. & 0.11 & 0.66 & Not Supported \\
\hline H2: PTs influences PS. & 0.21 & 1.20 & Not Supported \\
\hline H3: SIT influences EE. & 0.75 & $4.05^{* *}$ & Supported \\
\hline H4: SIT influences SCB. & 0.52 & $3.26^{* *}$ & Supported \\
\hline H5: SIT influences PS. & 0.46 & $2.49^{*}$ & Supported \\
\hline H6: PS influences SCB. & 0.22 & $2.34^{*}$ & Supported \\
\hline H7: EE influences PS. & 0.13 & 1.47 & Not Supported \\
\hline H8: EE influences SCB. & 0.31 & $2.33^{*}$ & Supported \\
\hline$* p \leq .05, * * p \leq .01$ & & &
\end{tabular}

$* p \leq .05, * * p \leq .01$ 


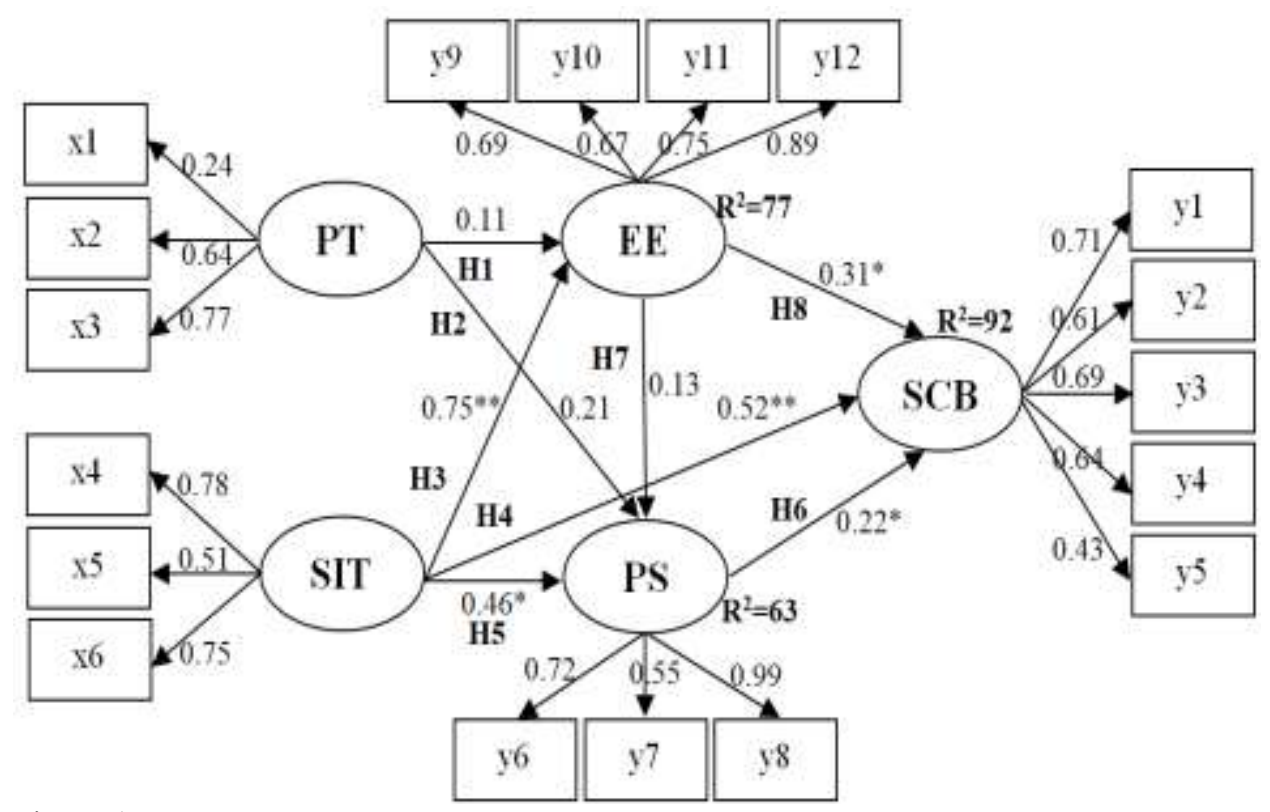

Figure 1

Final causal relationship model for Thai student teacher SCB

$* p \leq .05, * * p \leq .01$

\section{DISCUSSION}

It was determined that all the SEM's causal variables positively influenced a Thai student teacher's SCB, which can be combined to explain the shared variance of the factors affecting SCB $\left(\mathrm{R}^{2}\right)$ by $92 \%$. Furthermore, from the analysis of the findings from the study, the following strengths and weaknesses were determined in the final modeling.

\section{Model Interrelationship Strengths (Strongest to Weakest)}

The standard Pearson's and Spearman's correlation coefficients strength interpretation indicates that values from $0.1-0.3$ are the weakest. Values from $0.4-0.6$ are considered moderate, while the strongest values are from $0.7-0.9$ (Akoglu, 2018). Finally, ' 1 ' is considered perfect. As such, the following hypotheses results are presented using these criteria.

\section{H3 SIT $\rightarrow_{\text {EE }}$}

The student teacher's SIT had the strongest influence within the model. Specifically, in $\mathrm{H} 3$ we find that the interrelationship of SIT to EE was very strong as the Coef. $=0.85$, $\mathrm{t}$ test $=18.21$, and $p \leq 0.01$. This strength is also supported from total effect (TE) value of 0.75. This hypothesis result also agrees with Steg et al. (2016) who determined that SIT stimulates the expression of environmental behavior, and that values affect the chronic 
strength of goals. Moreover, Taufik et al. (2015) suggested that acting proenvironmentally, can make people feel good about themselves. Young et al. (2010), added that knowledge, influence, conclusion, implementation and affirmation at the behavioral adoption stage in the ongoing goal for SD.

\section{H4 SIT $\rightarrow$ SCB}

In $\mathrm{H} 4$ we find a moderate interrelationship between SIT and SCB as the Coef. $=0.52$, ttest $=3.26$, and $p \leq 0.05$. This strength is also supported from total effect (TE) value of 0.87. This hypothesis result also agrees with Endler and Magnusson (1978) who suggest that individuals use information about situations to moderate and shape their behaviour. In addition to direct experiences, students learn from observing others surrounding them, such as media, friends, and parents (Asmuni et al., 2012; Iyengar et al., 2009). This demonstrates that the observation of the SCB of others also has an influence on our own behavior.

H5 SIT $\rightarrow$ PS

Once again in H5 we find a moderate interrelationship between SIT and PS as the Coef. $=0.46$, t-test $=2.49$, and $p \leq 0.01$. This strength is also supported from total effect (TE) value of 0.55 . This hypothesis result is also in agreement with Salazar et al. (2013) who studied the social influence of peer groups such as friends, colleagues, and family on environmentally friendly products and discovered clear evidence for 'herd behaviour' and the support for 'social learning' effects. The primary difference being that social learning requires an exchange of information (Foster \& Rosenzweig, 1995).

\section{$\mathrm{H} 8 \mathrm{EE} \rightarrow \mathrm{SCB}$}

In $\mathrm{H} 8$ a weak but positive interrelationship between EE and SCB was determined as the Coef. $=0.31$, t-test $=2.33$, and $p \leq 0.01$. This strength is also supported from total effect (TE) value of 0.34. This hypothesis result also agrees with Frantz and Mayer (2009) and Steg and Vlek (2009) who have suggested that education is essential in encouraging proenvironmental behaviour, as students need to know the environmental impact of different environmental actions, what specific actions they could take to reduce environmental problems, how to undertake them, and what benefits such actions may have.

H6 PS $\rightarrow$ SCB

Also, in H6, a weak but positive interrelationship between PS and SCB was determined as the Coef. $=0.22$, t-test $=2.34$, and $p \leq 0.01$. This strength is also supported from total effect (TE) value of 0.22. This is consistent with Gotyal et al. (2010) who indicated that PS is another form of the mental process. This is a dynamic style where there are many qualitative and/or quantitative changes resulting from the present situation combined with the nature of the individual's spirituality (Berkman \& Lieberman, 2011), which is, therefore, closely related to behaviour. Bhanthumnavin (2017), also reported that the PS was the most important factor in a student's potential. 


\section{Rejected Hypotheses \\ $\mathrm{HIPT}^{\rightarrow}{ }_{\mathrm{EE}}$}

From the study it was determined that PTs are an indirect causal factor, which can have an influence on student teacher SCB. However, it is only an indirect influence via PS variables and EE. Furthermore, from the study, it was determined that the development or promotion of PTs may not directly change the student teacher's SCB in an improved manner. However, it does stimulate the occurrence of the PS and EE, leading to the students having SCB. These PTs are classified as personal factors, consisting of environmental concern, knowledge, consumer efficiency awareness, environmental awareness, and personality. Therefore, it may be inferred that this factor has an important influence on SCB (Kostadinova, 2016). This is in agreement with studies from Wu and Chen (2014) and Yadav and Pathak (2017), who found that the perceived behavior control of consumers had a positive influence on the intention to buy green products. In addition, Bhanthumnavin (2017) also found that PT had an influence on the potential of students via the PS.

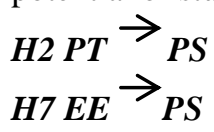

\section{CONCLUSION}

The study sought to examine and model the factors influencing a Thai student science teacher's sustainable consumption behaviour (SCB). The analysis determined that all the causal factors in the model had an influence on the student teacher's SCB, which can be explained by the combined influence of the factors $\left(\mathrm{R}^{2}\right)$ being $92 \%$. Each student's situation (SIT) was also determined to have a significant influence on both their EE and SCB. These factors for SIT included the examples set by their friends, and by extension, 'peer pressure', their awareness of the social norms, and examples from their parents. It is also noteworthy to the study that the sample of 400 student teachers has now moved on to their respective institutions as teachers. With their heightened degree of awareness of the critical nature of ESD from the study, they now have the ability and potential to be the leaders of change.

\section{ACKNOWLEDGEMENTS}

This research is supported by the Research Fund, King Mongkut's Institute of Technology Ladkrabang (KMITL), Bangkok, Thailand. The author would like to express their sincere thanks for this opportunity. 


\section{REFERENCES}

Ajzen, I., \& Fishbein, M. (1980). Understanding attitudes and predicting social behavior. Prentice-Hall.

Akoglu, H. (2018). User's guide to correlation coefficients. Turkish Journal of Emergency Medicine, 18(3), 91 - 93. https://doi.org/10.1016/j.tjem.2018.08.001

Asmuni, S., Khalili, J. M., \& Zain, Z. M. (2012). Sustainable consumption practices of students in an urban settings: A case in Selangor. Procedia - Social and Behavioral Sciences, 36, 716 - 722. https://doi.org/10.1016/j.sbspro.2012.03.078

Bajpai, V., \& Saha, A. (2020). Personal, Psychological Situational and Communicational Profile of the Gram Cultivators in Hamirpur District of UttarPradesh, India. International Journal of Current Microbiology and Applied Sciences, 9(3), 22652277. https://doi.org/10.20546/ijcmas.2020.903.257

Barclay, D., Higgins C. \& Thompson, R. (1995). The partial least squares (PLS): approach to causal modeling: personal computer adoption and use as an illustration. Technology Studies, 2(2), 285-309. https://tinyurl.com/uk6m4bh

Berkman, E. T., \& Lieberman, M. D. (2011). What's outside the black box?: The status of behavioral outcomes in neuroscience research. Psychological Inquiry, 22(2), 100 107. https://doi.org/10.1080/1047840x.2011.550182

Bhanthumnavin, D. (1995). Psychological theory of moral and work behaviors: Research and applications. National Institute of Development Administration (NIDA).

Bhanthumnavin, D. (2000). Ethical Tree Theory: Research and Development (2nd ed.). Chulalongkorn University Printing House.

Bhanthumnavin, D. (2017). Psycho-social antecedents of research potentiality among graduate students: A SEM approach. International Journal of Behavioral Science, 12(2), 50 - 70. https://so06.tci-thaijo.org/index.php/IJBS/article/view/94360

Boonkua, A., Tuntinakorngul, A., \& Tungkunanan, P. (2020). Innovative Organization's Components in Basic Education Institutions in Thailand. International Journal of Instruction, 13(3), OnlineFirst. https://tinyurl.com/yburqp54

Bowers, K. S. (1973). Situationism in psychology: An analysis and a critique. Psychological Review, 80(5), 307 - 336. https://doi.org/10.1037/h0035592

Brown, T. A. (2015). Confirmatory Factor Analysis for Applied Research (2nd ed.). The Guilford Press.

Carneiro, J., da Rocha, A., \& da Silva, J. F. (2009). Proposal of a validation framework for a new measurement model and its application to the export performance construct. Brazilian Administration Review, 6(4), 331 - 353. https://doi.org/10.1590/s180776922009000400005 
Campbell, D. T., \& Fiske, D. W. (1959). Convergent and discriminant validation by the multitrait-multimethod matrix. Psychological Bulletin, 56(2), 56-81. https://tinyurl.com/y33zfl72

Curran, P. S., West, S. G., \& Finch, J. F. (1996). The robustness of test statistics to nonnormality and specification error in confirmatory factor analysis. Psychological Methods, 1(1), 16 - 29. https://doi.org/10.1037/1082-989x.1.1.16

Endler, N. S., \& Magnusson, D. (Eds). (1976). Interactional psychology and personality. Halsted-Wiley.

Endler, N. S., \& Magnusson, D. (1978). But interactionists do believe in peoplep Response to Krauskopf. Psychological Bulletin, 85(3), 590-592. https://doi.org/10.1037/0033-2909.85.3.590

Endler, N. S. (1983). Interactionism: A personality model, but not yet a theory. Nebraska Symposium on Motivation, 155 - 200. http://tinyurl.com/gprbxbl

Engel, C., \& Weber, E. U. (2007). The impact of institutions on the decision How to decide. Journal of Institutional Economics, 3(3), 323 - 349. https://doi.org/10.1017/s1744137407000744

Farrell, A. M. (2010). Insufficient discriminant validity: A comment on Bove, Pervan, Beatty, and Shiu (2009). Journal of Business Research, 63, 324 - 327. https://doi.org/10.1016/j.jbusres.2009.05.003

Fishbein, M., \& Ajzen, I. (1975). Belief, attitude, intention, and behavior: An introduction to theory and research. Addison-Wesley.

Fornell, C., Johnson, M. D., Anderson, E. W., Cha, J., \& Bryant, B. E. (1996). The American customer satisfaction index: Nature, purpose, and findings. Journal of Marketing, $\quad 60(4), \quad 7-14 . \quad$ https://doi.org/10.1016/j.jbusres.2009.05.003 $10.2307 / 1251898$

Foster, A. D., \& Rosenzweig, M. R. (1995). Learning by doing and learning from others: human capital and technical change in agriculture. Journal of Political Economy, 103(6), 1176-1209. https://doi.org/10.1086/601447

Frantz, C. M., \& Mayer, G. S. (2009). The emergency of climate change: Why are we failing to take action? Analyses of Social Issues and Public Policy, 9(1), 205-222. https://doi.org/10.1111/j.1530-2415.2009.01180.x

George, D., \& Mallery, P. (2010). SPSS for Windows step by step: A simple guide and reference 17.0 update. Pearson.

Gotyal, S. H., Angadi, J. G., Aski, S. G., Patil, M. B., \& Dolli, S. S. (2010). Personal psychological situational and communicational profile of the grape growers in Bijapur District of Karnataka. International Journal of Agricultural and Statistical Science, 6(2), 557-564. 
Hair, J. F., Black, W. C., Babin, B. J., \& Anderson, R. B. (2009). Multivariate data analysis (7th ed.). Prentice Hall.

Hair, J. F., Hult, G. T. M., Ringle, C. M., \& Sarstedt, M. (2013). A primer on partial least squares structural equation modelling (PLS-SEM). Sage.

Henseler, J., Ringle, C. M., \& Sarstedt, M. (2014). A new criterion for assessing discriminant validity in variance-based structural equation modeling. Journal of the Academy of Marketing Science, 43(1), 115-135. https://doi.org/10.1007/s11747-0140403-8

Hooper, D., Coughlan, J. \& Mullen, M. (2008). Structural equation modelling: Guidelines for determining model fit. Electronic Journal of Business Research Methods, 6(1), 53-60. https://tinyurl.com/y37qq4pe

Hu, L. T., \& Bentler, P. M. (1999). Cutoff criteria for fit indexes in covariance structure analysis: Conventional criteria versus new alternatives. Structural Equation Modeling, 6(1), 1 - 55. https://doi.org/10.1080/10705519909540118

Hungerford, H. R., \& Volk, T. L. (1990). Changing learner behavior through environmental education. Journal of Environmental Education, 21(3), 8-21. https://doi.org/10.1080/00958964.1990.10753743

Inayatullah, S. T. (Ed.). (2009). Global transformations and world futures: Knowledge, economy, and society. Eolss Publishers.

Iyengar, R., Han, S., \& Gupta, S. (2009). Do friends influence purchases in a social network? Harvard Business School: Working Paper. 09-123. https://hbswk.hbs.edu/item/do-friends-influence-purchases-in-a-social-network

Jöreskog, K. G., Olsson, U. H., \& Fan, Y. W. (2016). Multivariate analysis with LISREL. Springer.

Kostadinova, E. (2016). Sustainable consumer behavior: Literature overview. Economic Alternatives, 2, 224-234. https://tinyurl.com/y8dzuou5

Ladhari, R. (2009). A review of twenty years of SERVQUAL research. International Journal of Quality and Service Sciences, l(2), 172-198. https://doi.org/10.1108/17566690910971445

Lance, C. E., Butts, M. M., \& Michels, L. C. (2006). The sources of four commonly reported cutoff criteria: What did they really say? Organizational Research Methods, 9(2), 202-220. https://doi.org/10.1177/1094428105284919

Leicht, A., Heiss, J., \& Byun, W. J. (Eds.). (2018). Issues and trends in education for sustainable development. UNESCO Publishing. https://tinyurl.com/y9y7dvel

Loehlin, J. C. (1992). Latent variable models. Lawrence Erlbaum Publishers. 
Luchs, M. G., Phipps, M., \& Hill, T. (2015). Exploring consumer responsibility for sustainable consumption. Journal of Marketing Management, 00, 1-23. http://dx.doi.org/10.1080/0267257X.2015.1061584

McMeekin, A., \& Southerton, D. (2012). Sustainability transitions and final consumption: practices and socio-technical systems. Technology Analysis \& Strategic Management, 24(4), 345 - 361. https://doi.org/10.1080/09537325.2012.663960

Minister of Foreign Affairs. (2018). Thailand's voluntary national review of the implementation of the 2030 Agenda for Sustainable Development 2018. https://tinyurl.com/ydxv97nd

Muijs, D., Kyriakides, L., van der Werf, G., Creemers, B., Timperley, H., \& Earl, L. (2014). State of the art - teacher effectiveness and professional learning. School Effectiveness and School Improvement, 25(2), 231-256. https://doi.org/10.1080/09243453.2014.885451

Narathakoon, A., Sapsirin, S., \& Subphadoongchone, P. (2020). Beliefs and classroom assessment practices of English teachers in primary schools in Thailand. International Journal of Instruction, 13(3), OnlineFirst. https://tinyurl.com/yded3q5m

Pimdee, P. (2017). Causal relationship model of Thai undergraduate student energy conservation behavior. Journal of Sustainability Science and Management, 12(2), 218227. https://tinyurl.com/y9a2nyc7

Ratner, B. (2009). The correlation coefficient: Its values range between $+1 /-1$, or do they? Journal of Targeting, Measurement and Analysis for Marketing, 17(2), 139-142. https://doi.org/10.1057/jt.2009.5

Ryan, S., \& Carr, A. (2010). Chapter 5 - Applying the biopsychosocial model to the management of rheumatic disease. In Rheumatology (pp. 63-75). Churchill Livingston. https://doi.org/10.1016/b978-0-443-06934-5.00005-x

Salazar, H. A., Oerlemans, L., \& van Stroe-Biezen, S. (2013). Social influence on sustainable consumption: Evidence from a behavioral experiment. International Journal of Consumer Studies, 37(2), 172-180. https://doi.org/10.1111/ j.14706431.2012.01110.x

Schumacker, R. E., \& Lomax, R. G. (2010). A beginner's guide to structural equation modeling. Routledge.

Sethna, Z., \& Blythe, J. (2019). Consumer behaviour. Sage. https://tinyurl.com/y97axudr

Sharma, M. \& Rani, L. (2014). Environmentally sustainable consumption: A review and agenda for future research. Global Journal of Finance and Management, 6(4), 367-374. https://tinyurl.com/y73kqtgr

Stapp, W. B. (1969). The concept of environmental education. Environmental Education, 1(1), 30-31. https://doi.org/10.1080/00139254.1969.10801479 
Steg, L., \& Vlek, C. (2009). Encouraging pro-environmental behaviour: An integrative review and research agenda. Journal of Environmental Psychology, 29(3), 309-317. https://doi.org/10.1016/j.jenvp.2008.10.004

Steg, L., Lindenberg, S. \& Keizer, K. (2016). Intrinsic motivation, norms and environmental behaviour: The dynamics of overarching goals. International Review of Environmental and Resource Economics, 9(1-2), 179 - 207. https://doi.org/10.1561/ 101.00000077

Tabachnick, B. G., \& Fidell, L. S. (2007). Using multivariate statistics (5th ed.). Allyn and Bacon.

Taufik, D., Bolderdijk, J. W., \& Steg, L. (2015). Acting green elicits a literal "Warm Glow"”. Nature Climate Change, 5, 37-40. https://doi.org/10.1038/nclimate2449

Tbilisi Declaration. (1977). https://www.gdrc.org/uem/ee/tbilisi.html

Tett, R. P., \& Burnett, D. D. (2003). A personality trait - based interactionist model of job performance. Journal of Applied Psychology, 88(3), 500-517. https://doi.org/10.1037/0021-9010.88.3.500

Trudel, R. (2019). Sustainable consumer behavior. Consumer Psychology Review, 2, 85 - 96. https://doi.org/10.1002/arcp.1045

Turner, R. C., \& Carson, L. (2003). Indexes of item-objective congruence for multidimensional items. International Journal of Testing, 3(2), 163-17. doi: 10.1207/S15327574IJT03025

United Nations. (2015). About the sustainable development goals. https://tinyurl.com/yafaeg9p

United Nations. (2020a). Quality education. https://tinyurl.com/y6lytyal

United Nations. (2020b). Goal 12: Ensure sustainable consumption and production patterns. https://tinyurl.com/yamgayyv

UNESCO. (2018). Integrating Education for Sustainable Development (ESD) in Teacher Education in South-East Asia. Project Review Workshop. 24-26 April 2018. Holiday Inn Sukhumvit, Bangkok, Thailand. https://tinyurl.com/y9pjuekb

Walsh, W. B., Craik, K. H., \& Price, R. H. (2000). Person-environment psychology (2nd ed.). LEA.

World Commission on Environment and Development (WCED). (1987). Our common future. Oxford University Press. https://tinyurl.com/y7cvzcpn

Wu, S.-I., \& Chen, J.-Y. (2014). A model of green consumption behavior constructed by the Theory of Planned Behavior. International Journal of Marketing Studies, 6(5), 119 132. https://doi.org/10.5539/ijms.v6n5p119 
Yadav, R, \& Pathak, G. S. (2017). Determinants of consumers' green purchase behavior in a developing nation: Applying and extending the Theory of Planned Behavior. Ecological Economics, 134, 114 - 122. https://doi.org/10.1016/j.ecolecon.2016.12. 019

Young, W., Hwang, K., Mcdonald, S., \& Oates C. J. (2010). Sustainable consumption: Green consumer behaviour when purchasing products. Sustainable Development, 18(1), 20-31. https://doi.org/10.1002/sd.394 